\section{Production of farmstead lactose-free Pecorino di Osilo and ricotta cheeses from sheep's milk}

\author{
Luisa Pulinas, ${ }^{1}$ Carlo Spanu, ${ }^{1}$ \\ Ilenia Idda, ${ }^{2}$ Ignazio Ibba, ${ }^{3}$ \\ Gavino Nieddu, ${ }^{4}$ Salvatore Virdis, ${ }^{1}$ \\ Christian Scarano, ${ }^{1}$ Francesca Piras, ${ }^{1}$ \\ Nadia Spano, ${ }^{2}$ Gavino Sanna, ${ }^{2}$ \\ Enrico Pietro Luigi De Santis ${ }^{1}$ \\ ${ }^{1}$ Department of Veterinary Medicine, \\ University of Sassari, Sassari; \\ ${ }^{2}$ Department of Chemistry and \\ Pharmacy, University of Sassari, \\ Sassari; ${ }^{3}$ Regional Association of \\ Sardinia Farmers, Oristano; ${ }^{4}$ Sheep \\ Breeders Cooperative, Oristano, Italy
}

quantification respectively of 1.8 and 5.6 $\mathrm{mg} / \mathrm{kg}$ for cheese, and 1.35 and $4.2 \mathrm{mg} / \mathrm{kg}$ for both ricotta cheeses. The lactose concentration was always below the relevant LOD values in all samples. The mean concentration of galactose and glucose were respectively $13,000 \pm 2000$ and $11,000 \pm 2000$ $\mathrm{mg} / \mathrm{kg}$ in fresh Pecorino di Osilo, $1100 \pm 300$ and $1200 \pm 300 \mathrm{mg} / \mathrm{kg}$ in fresh ricotta, and $950 \pm 400$ and $750 \pm 250 \mathrm{mg} / \mathrm{kg}$ in Ricotta mustia. The results of the present study showed that the production of farmstead lactose-free Pecorino di Osilo cheese and ricotta cheeses from raw sheep's milk is easily achievable. The main issue for farmstead production of artisanal lactose-free products is the implementation of permanent procedures based on hazard-analysis and critical control principles aimed at guaranteeing the effectiveness of the process and at acquiring analytical evidences to demonstrate the fulfilment of law requirements for labelling.

\section{Abstract \\ The present work was aimed to define} and validate farmstead production of lactose-free Pecorino di Osilo cheese, fresh ricotta cheese, and salted and smoked ricotta cheese (Ricotta mustia). The enzymatic activity of the commercial preparation containing lactase $(1.1 \mathrm{~g} / \mathrm{mL})$, preliminarily tested using a spectrophotometric titration, showed activity equal to $4950 \pm 40$ neutral lactase unit/g. The amount of lactase required to obtain the lactose-free milk was then established in triplicate laboratory trials, by adding the enzyme at concentrations of $0.7,0.9$ and $1.1 \mathrm{~g} / \mathrm{L}$ in flasks containing $160 \mathrm{~mL}$ of raw sheep's milk. Samples were incubated under conditions expected during milk storage and cheese-making. The residual lactose content in milk was determined by enzymatic method. The addition of lactase at concentration of $1.1 \mathrm{~g} / \mathrm{L}$ of milk reduced the lactose concentration below the limit of detection (LOD) of $0.06 \mathrm{~g} / \mathrm{L}$. The procedure was validated at a dairy farm, using three different batches of bulk raw sheep's lactose-free milk that were transformed into Pecorino di Osilo cheese. The resulting whey was used to produce fresh ricotta and Ricotta mustia cheese. Raw milk and whey samples were always below lactose detection limit. The residual lactose was measured in Pecorino di Osilo cheese, after 24 hours and 30 days from production; in fresh ricotta cheese, after 48 hours; in Ricotta mustia cheese after 7 days. The determination of lactose content in cheese samples was conducted by a gas chromatography-flame ionization detection method, which showed a LOD and limit of

\section{Introduction}

Lactose, the main saccharide of milk, is composed of D-galactose and D-glucose joined by a $\beta$-1.4-glycosidic linkage. The intestinal absorption of lactose by the epithelium of the human colon needs the enzymatic hydrolysis into monosaccharides by $\beta$-galactosidase (EC 3.2.1.23). This enzyme is found most abundantly in the villus enterocytes of the jejunum (Lule et al., 2016). In mammals the lactase production progressively stops after weaning and the adults lose their ability to digest lactose, while humans can keep lactase production also in adults (Jelen and Tossavainen, 2003). Hypolactasia, lactose maldigestion or, less properly, malabsorption, are synonyms indicating a deficiency in the lactase enzyme (Kies, 2014). Lactose maldigesters are those human adults with a genetic deficiency in lactase production (primary adult hypolactasia). A large part of the human population is represented by lactase nonpersistent people, as they undergone to a genetic programmed reduction in the lactase synthesis between 5 and 14 years of age, to level as low as $5-10 \%$ of the production observed in infants. Secondary lactase deficiency (or acquired hypolactasia) could also be caused by damage of the intestinal mucosa due to chemotherapy, acute viral or bacterial infection and infestation by parasites. A rare congenital form (caused by an autosomal recessive disorder) and a developmental lactase deficiency, occurring in premature babies with less than 34 weeks of gestation, have been also described (Lule et al., 2016).
Correspondence: Carlo Spanu, Department of Veterinary Medicine, University of Sassari, via Vienna 2, 07100 Sassari, Italy.

Tel: +39.079.229447 - Fax: +39.079.229458.

E-mail: cspanu@uniss.it

Key words: Sheep's milk; Ricotta cheese; Lactose-free.

Conflict of interest: the authors declare no potential conflict of interest.

Funding: this work was funded by Chamber of Commerce of Sassari, Bonas in novas programme.

Received for publication: 19 October 2016. Revision received: 13 December 2016.

Accepted for publication: 16 December 2016.

This work is licensed under a Creative Commons Attribution-NonCommercial 4.0 International License (CC BY-NC 4.0).

(C) Copyright L. Pulinas et al., 2017

Licensee PAGEPress, Italy

Italian Journal of Food Safety 2017; 6:6353

doi:10.4081/ijfs.2017.6353

Undigested lactose can be fermented by intestine microflora producing gaseous byproducts like hydrogen, carbon dioxide and methane. In addition, the osmotic gradient created by the undigested lactose results in an influx of liquids which causes diarrhea. Clinical symptoms of lactose intolerance (LI) include abdominal pain, cramps, abdominal bloating, asthenia, loose stools or diarrhea (sometimes constipation), occurring after 1-2 hours from the ingestion of foods containing lactose (Beyerlein et al., 2008; Lule et al., 2016). Since LI depends on the amount of ingested lactose and the severity of symptoms varies from person to person, the amount of ingested lactose required to produce illness cannot be defined. Symptoms of LI have been described after the ingestion of as little as 6 $\mathrm{g}$ of lactose, but generally the ingestion up to $12 \mathrm{~g}$ of lactose as a single dose is tolerated by the vast majority of subjects with lactose maldigestion. If assumed distributed during the day, higher doses of lactose can be tolerated (EFSA, 2010). It was estimated that approximately $70 \%$ of the world's population produce low level of lactase and that the frequency of LI varies largely between geographical areas and populations (Kies, 2014; Lule et al., 2016). Casellas et al. (2010) demonstrated that conventional anamnesis reported by patients after the ingestion of lactose-containing foods are a highly unreliable tool to establish symptomatic lactose malabsorption since abdominal symptoms can have causes beyond lactose malabsorption. Low-lactose and lac- 
tose-free products are obtained in the dairy industry by the hydrolysis of lactose in milk using the enzyme beta-galactosidase (lactase), by chromatographic separations or by use of membrane separation, that could be also combined with lactose hydrolysis techniques (Jelen and Tossavainen, 2003). The hydrolysis of lactose, obtained by means of free or immobilized lactase (Horner et al., 2011), can influence both the technological and the sensorial properties of products. Lactose hydrolysis could also results in transgalactosylation reactions, in which glucose and galactose released by hydrolysis served as galactosyl acceptors, producing oligosaccharides with prebiotic activity. Lactase can be of animal, plant and microbial origin. The latter is the most common and is generally obtained from fungi ( $A$. niger, A. oryzae), yeast (Kluyveromyces lactis, Kluyveromyces marxianus, Saccharomyces fragilis) and lactic acid bacteria (Bifidobacterium spp., Bacillus spp., E. coli) (Oliveira et al., 2011). The molecular weight, the amino-acids chain length, the position of the active site, the $\mathrm{pH}$ and the temperature of optimal activity of betagalactosidase could significantly vary when changing the microbial origin of the enzyme (Mlichová and Rosenberg, 2006). Lactases from bacteria and yeasts are the most commonly used in the dairy industry since they have the optimal activity at $\mathrm{pH}$ between 6 and 7. The use of beta-galactosidase from fungal origin, which shows the highest activity at $\mathrm{pH}$ between 3 and 4 , is generally associated to hydrolysis in acid milk and cream (Chen et al., 2009). Mesophilic lactase show the highest activity at $\mathrm{ca} .30^{\circ} \mathrm{C}$, while thermostable lactases are effective until $50-65^{\circ} \mathrm{C}$ and temperature $<15^{\circ} \mathrm{C}$ are needed for cold-active lactases (Mlichová and Rosenberg, 2006; Horner et al., 2011). The EU regulatory framework governing lactose-free foods (or low lactose foods) has just been changed (European Commission, 2013). On July 20 2016 entered in force the Regulation (EU) No $609 / 2013$ on food intended for infants and young children, food for special medical purposes and total diet replacement for weight control. It has repealed the Directive 2009/39/EC of the European Parliament on foodstuffs intended for particular nutritional uses. On the other hand, the lactose-free product labelling is ruled by art. 36 (voluntary food information) of Regulation (EU) No $1169 / 2011$ on the provision of food information to consumers (European Commission, 2011). Until the harmonization of the law in the European Union is completed, in Italy it is still possible labelling a food as lactose-free if its lactose amount is $<0.1 / 100 \mathrm{~g}$ or $\mathrm{mL}$, whereas low in lactose is admitted for fluid and fermented milk when the lactose concentration is less than $0.5 / 100 \mathrm{~g}$ or $\mathrm{mL}$ (Italian Ministry of Health, 2015). These values are referred also to a naturally lactose-free or a naturally low in lactose indications, that characterize dairy product in which the lactose is naturally hydrolyzed during the manufacturing process (e.g. cheeses with extended ripening) (Italian Ministry of Health, 2016a). An approval process for dairy industries that produce products without lactose is no longer required by the Competent Authority as before, but the adoption of a specific hazard-analysis and critical control points (HACCP) procedure by food business operators is considered advisable (Italian Ministry of Health, 2016b). The increase of the consumer's awareness about food allergy and intolerance drove the interest and continuous growth of lactose-free products on the market. The overall global demand of lactose-free milk and dairy products showed an increasing trend over the last years, with $+8 \%$ in USA market in 2015 (Baroke, 2016). The island of Sardinia (Italy) is one the most productive areas for sheep's milk, accounting for about $66 \%$ of total Italian production (ISTAT, 2015). Almost all the Sardinian production is transformed into cheeses and other valuable niche dairy products. Pecorino di Osilo is one of the most renowned sheep cheeses of Sardinia. It is a raw or semi-cooked curd sheep cheese, available in different versions depending from the ripening duration (from 2-3 weeks to 6 months). The fresh ricotta cheese is a sheep cheese made from whey resulting from the Pecorino cheeses production. Sheep's whey, sometimes added of fresh, raw milk or cream, is heated at 80$82^{\circ} \mathrm{C}$ to obtain the denaturation of globulins and albumins, which coagulate in a fine curd. Curd is separated by the liquid by means of perforated scoop or by filtering the mixture with a fine linen cloth, which retains it. The Ricotta mustia cheese is pressed, salted, dried and then light smoked. Pecorino, fresh ricotta cheese and Ricotta mustia cheese are also included in the list of traditional Italian food products (MIPAAF, 2016). The present research was carried out in the frame of a project aimed to obtain lactose-free products, in cooperation with a Sardinian farmstead cheesemaker (Bonas in-novas programme). The principal objectives of the work were: i) to establish the lactase amount to achieve lactose-free raw sheep's milk in farmstead production conditions; ii) and to validate the whole production process of Pecorino di Osilo cheese, fresh ricotta and Ricotta mustia cheeses obtained from lactose-free sheep's milk and whey.

\section{Materials and Methods}

\section{Enzymatic hydrolysis of lactose in sheep's milk and technology of production of lactose-free sheep's cheeses}

\section{Commercial $\beta$-galactosidase enzyme}

The commercially available $\beta$-galactosidase enzyme HA-Lactase (Chr. Hansen, Hoersholm, Denmark) produced by Kluyveromyces lactis was used in the present study. According to supplier indication, the enzymatic concentration of HA-Lactase is $1.1 \mathrm{~g} / \mathrm{mL}$, with an activity level of 5200 neutral lactase unit (NLU)/g. The recommended dosage for the enzyme in milk is between 500 and 4000 NLU/L, and the optimal hydrolytic activity is ensured working at temperature between 35 and $45^{\circ} \mathrm{C}$ and a $\mathrm{pH}$ value between 6 and 7 .

\section{Enzymatic hydrolysis of lactose in sheep's milk}

The conditions of enzymatic hydrolysis of lactose in sheep's milk were preliminarily assessed in a laboratory scale. Here, the compatibility of the principal variables of process (i.e. the concentration of lactase, the temperature of milk and its time of exposition to lactase) was optimized on the basis of the needs of farmstead cheesemaker during the phases of milk storage and cheese making process. A laboratory trial was planned considering that the Pecorino di Osilo cheese is typically produced with the milk harvested from two consecutive milking (morning milking and evening milking). The production procedure at the farm prescribed that the amount of lactase needed to hydrolyze the lactose of the entire milk daily production was added immediately after the morning milking. The daily milk production was estimated on the average amount of the previous week and, if necessary, during the evening milking the lactase was eventually adjusted to the effective milk yield. The laboratory trial was carried out adding decreasing amount of commercial lactase to a first aliquot of $80 \mathrm{~mL}$ of refrigerated raw sheep's milk in $250 \mathrm{~mL}$ glass flasks. After $12 \mathrm{~h}$ (time T12), the second $80 \mathrm{~mL}$-aliquot of the refrigerated raw sheep was added in each flask. The lactase was added to the milk (two aliquots, 160 $\mathrm{mL}$ ) to reach the final concentrations, respectively, of $1.1 \mathrm{~g} / \mathrm{L}$ (lactase amount 160 $\mu \mathrm{L}), 0.9 \mathrm{~g} / \mathrm{L}(130.9 \mu \mathrm{L})$ and $0.7 \mathrm{~g} / \mathrm{L}(101.8$ $\mu \mathrm{L})$. The three concentrations were selected based on the indications provided by the manufacturer's instructions. Then, preliminary laboratory trials were conducted to assess the lower concentration of lactase that guarantees a level of residual lactose 
below the detection limit of $0.06 \mathrm{~g} / \mathrm{L}$ (data not showed). Finally, all flasks were first stored at $8^{\circ} \mathrm{C}$ for further 12 hours (time $\mathrm{T}_{24}$ ), then they were heated and held at $35^{\circ} \mathrm{C}$ for $65 \mathrm{~min}$ before the analysis, in order to simulate conditions adopted during the cheese making. The experiment was carried out in triplicate for each lactase concentration. Three flasks containing each $160 \mathrm{~mL}$ of untreated raw milk were used as controls.

\section{Technology of production of lactose-free Pecorino di Osilo cheese}

The farmstead Pecorino di Osilo sheep cheese was produced in a local farm from April to May 2015. The raw milk collected during morning milking was stored in a refrigerated tank at $8^{\circ} \mathrm{C}$. According to the laboratory protocol, all the lactase $(35 \mathrm{~mL})$ necessary for the estimated full daily milk production (350 L) was added just after the morning milking to obtain an enzyme concentration of $1.1 \mathrm{~g} / \mathrm{L}$ (as determined with the preliminary assay). After 12 hours, the milk of the evening milking was added in the same tank, and the milk was stored for further 12 hours. Cheese production was made in a tinned copper cauldron. Here, a portion of the raw delactosed milk (315 L) was pre-heated at $35^{\circ} \mathrm{C}$ and inoculated with a starter culture, then coagulated with $5 \mathrm{~g} / 100 \mathrm{~L}$ of calf rennet powder [Caglificio Clerici spa, Cadorago (CO), Italy]. The clotting took place in 20 min followed by curd firming of approximately $12 \mathrm{~min}$. The curd was cut into ricegrain sized particles and heated at $42-43^{\circ} \mathrm{C}$ for $\mathrm{ca} .15 \mathrm{~min}$. Curds were molded and held in a warm chamber $\left(42-43^{\circ} \mathrm{C}\right.$ for $\left.3-4 \mathrm{~h}\right)$ for the acidification. Cheese was salted for $24 \mathrm{~h}$ in saturated sodium chloride brine at 10$12^{\circ} \mathrm{C}$; in this time-lapse, $\mathrm{NaCl}$ was added to the rising surface of the wheel. Ripening was conducted in cave at constant temperature between 12 and $14^{\circ} \mathrm{C}$ for a period between 20 days and 4-6 months. Cheese wheels were periodically turned over and spread on the surface with a mixture of olive oil and vinegar. The average weight of each cheese wheel was of $1.7 \mathrm{~kg}$.

\section{Technology of production of lactose-free fresh ricotta and Ricotta mustia cheeses}

The whey remaining after the production of cheese $(230 \mathrm{~L})$ was added with sodium chloride $(25 \mathrm{~g})$, heated in large open kettles and stirred at a low speed. When the temperature rose up to $55-60^{\circ} \mathrm{C}$ the whey was blended with $35 \mathrm{~L}$ of lactose-free raw milk per kettle. Heating of the whey/milk mixture was continued to $78-80^{\circ} \mathrm{C}$ when the curd started floating; after this point, heating was held for few min. Curds were scooped with perforated ladles and transferred into polyethylene perforated baskets of conical-truncated shape, allowed to cool for $c a .4$ hours then refrigerated at $4^{\circ} \mathrm{C}$. The average weight of each basket of fresh ricotta was ca. $0.4 \mathrm{~kg}$.

The production of Ricotta mustia cheese differed from fresh ricotta cheese only in the use, unlike of the baskets, of perforated polyethylene cylindrical molds in order to better drain the curd. After $c a$. 60 min the curd was extracted, the molds were lined with cheese cloths and the curds put back into the molds and cooled at $4{ }^{\circ} \mathrm{C}$ for about 5 hours. The curd was then pressed for 8-10 hours with the use of a wooden cheese press. Ricotta was then removed from cloths and was dry salted for 12 hours and exposed to smoke of wood for 3 hours within a traditional smoking chamber. The ricotta wheels were dried with natural airflow and stored at $4{ }^{\circ} \mathrm{C}$ and immediately marketed or ripened. The average weight of each Ricotta mustia wheel was $1.0 \mathrm{~kg}$.

\section{Analysis}

\section{Determination of the $\beta$-galactosidase activity}

The activity of the commercial $\beta$-galactosidase enzyme was assayed using the official spectrophotometric method proposed by AOAC (AOAC, 1999). In the presence of lactase, the colorless $o$-nitrophenyl- $\beta$-Dgalactopyranoside (ONPG) is hydrolyzed into galactose and $o$-nitrophenol (ONP), a yellow compound. In this way the enzymatic activity is obtained by measuring the absorbance of the ONP chromophore. In particular, $1 \mathrm{NLU}$ is the quantity of enzyme that liberates $1.30 \mu \mathrm{M}$ ONP under assay conditions (AOAC, 1999).

The $\beta$-galactosidase was dissolved in a buffered solution $\left(0.2 \mathrm{M}\right.$ in $\mathrm{K}_{3} \mathrm{PO}_{4}, 0.1 \mathrm{mM}$ in $\mathrm{C}_{10} \mathrm{H}_{14} \mathrm{~N}_{2} \mathrm{Na}_{2} \mathrm{O}_{8} .2 \mathrm{H} 2 \mathrm{O}, 0.1 \mathrm{mM}$ in $\mathrm{MgCl}_{2}$; $\mathrm{pH} 6.50 \pm 0.05$; acronym: PEM) to obtain a working solution with an enzymatic activity of $0.075 \pm 0.010 \mathrm{NLU} / \mathrm{mL}$. Test tubes were prepared in triplicate mixing $1 \mathrm{~mL}$ of this working solution and an aqueous solution of $o$-nitrophenyl- $\beta$-D-galactopyranoside, ( 5 $\mathrm{mL}, 5.2 \mu \mathrm{M} / \mathrm{mL}$ ). This mixture was hence dispensed into bovine serum albumin (1\% solution in PEM) coated glass tubes. Tubes were first placed in a thermostatic shaking water bath kept at $30 \pm 1^{\circ} \mathrm{C}$ for $10 \mathrm{~min}$ at 250 $\mathrm{rpm}$, and then $2 \mathrm{~mL}$ of $1 \mathrm{M}$ aqueous solution of $\mathrm{Na}_{2} \mathrm{CO}_{3}$ were added in order to stop the reactions. ONP absorbance was read at 420 $\mathrm{nm}$ on a spectrophotometer Shimadzu UV1700 (Shimadzu, Kyoto, Japan). Calibration was conducted using standard solutions of ONP in the concentration range between 0.02 and $0.14 \mu \mathrm{M} / \mathrm{mL}$. The excellent linearity of the method was proved by the high values of the correlation coefficient $\left(\mathrm{R}^{2}\right)$, typically over 0.99 . Finally, the enzy- matic activity was computed using the following equation:

$$
\mathrm{NLU} / \mathrm{g}=(A \times 8 \times f) /(4.65 \times 10 \times 1.30)
$$

where $A$ is the absorbance, corrected for test blank; 8 is the volume $(\mathrm{mL})$ of incubation mixture after termination; $f$ is the total dilution factor of test solution; 4.65 is the absorptivity; 10 is the incubation time ( $\mathrm{min}$ ) and 1.30 is the factor used in NLU definition.

\section{Analytical characterisation of sheep's milk}

The determination of proteins, fats, lactose and $\mathrm{pH}$ in raw bulk milk samples was conducted using Fourier transform infrared spectrometry (MilkoScan 6000; Foss Electric, Hillerød, Denmark). Calibration was developed according to ISO 9622:2013/IDF 141:2013 (ISO, 2013). Somatic cell count was performed by flow cytometry counter (Fossomatic 5000; Foss Electric) according to ISO 13366:2006/IDF148:2006 (ISO, 2006). Total bacterial count was conducted by automatic flow cytometry determination method using Bactoscan FC (Foss Electric). In delactosed milk samples, the determination of residual lactose content was performed by enzymatic method using differential $\mathrm{pH}$ measurement according to ISO 26462:2010 (IDF 214:2010; ISO, 2010). Comparison of mean proteins, fat and lactose content (\%), somatic cell counts, total bacteria counts $(\log 10 \mathrm{cfu} / \mathrm{g})$ and $\mathrm{pH}$ between batches was conducted using Fisher's LSD test. All statistical analyses were performed with Statgraphics Centurion XVI software (Stat Point Technologies, Warrenton, VA, USA).

\section{Analytical characterisation of farmstead lactose-free sheep's cheeses}

Pecorino di Osilo cheese samples were analyzed 30 days from production, fresh ricotta after $48 \mathrm{~h}$ whereas Ricotta mustia 2 and 7 days after production. Three samples for each of 3 production batches were analyzed. The determination of proteins, fats, moisture and $\mathrm{NaCl}$ was conducted by Nearinfrared reflectance spectroscopy (NIRS) (Food Scan Lab; Foss Electric). The pH was determined with potentiometric measurement (GLP 22; Crison Instruments, Alella, Spain). Determination of $\mathrm{a}_{\mathrm{w}}$ was conducted using Aqua Lab (Decagon Devices, Inc., Pullman, PA, USA).

Gas chromatography-flame ionisation detection determination of lactose, glucose and galactose in farmstead lactosefree sheep's cheeses

All samples were kept in the dark and 
stored at $+4^{\circ} \mathrm{C}$ until analysis, which has been performed 24 hours from the production for Pecorino di Osilo cheese, 2 days from the production for fresh ricotta cheese and 7 days from production for Ricotta mustia cheese. The reagents used were all analytical grade. D-lactose, D-glucose, Dgalactose, methyl $\alpha$-D-galactopyranoside, pyridine, heptane, N-trimethylsilylimidazole (TMSI), trimethylchlorosilane (TMCS), methanol and ethanol were purchased from Sigma Aldrich (Milan, Italy). Ultrapure (Type 1) water (specific resistance $18 \mathrm{M} \Omega$ ) was always used throughout the analyses. Due the complexity of the matrix, a proper pretreatment of sample was needed to remove proteins, which have to be separated from saccharides before their derivatization. In close analogy to what experienced (Idda et al., 2016; Troyano et al., 1991, 1994, 1996), the proteins were separated from analytes by precipitation with lower alcohols such as methanol or ethanol. An appropriate choice of the nature of the alcohol and of the amount of the sample $(0.5000$ and $10.000 \mathrm{~g}$, respectively) allowed us to ensure flexibility to the method here proposed. Sample pretreatment procedures used for Pecorino di Osilo and ricotta cheese are reported below. The differences in the amount of lactose, galactose, glucose and galactose/glucose/ratio between fresh ricotta, Ricotta mustia and Pecorino di Osilo were compared using Fisher's LSD test. All statistical analyses were performed with Statgraphics Centurion XVI software (Stat Point Technologies).

Sample pretreatment of Pecorino di Osilo sheep's cheese was made by mixing $10 \mathrm{~g}$ of Pecorino di Osilo cheese with 500 $\mathrm{mL}$ of a $1 \%(\mathrm{w} / \mathrm{v})$ internal standard aqueous solution and suspending them into 25 $\mathrm{mL}$ of a $40 \%(\mathrm{v} / \mathrm{v})$ methanol/water solution. The mixture was first homogenized for 10 minutes and then sonicated at $42^{\circ} \mathrm{C}$ for 10 minutes into an ultrasonic bath. The mixture was then centrifuged at $2000 \mathrm{rpm}$ for 15 min and the supernatant was separated by the residue, which was treated again with another $25 \mathrm{~mL}$ aliquot of a $40 \%(\mathrm{v} / \mathrm{v})$ methanol/water solution, according to the procedure described above. Both the solutions obtained were collected in a $50-\mathrm{mL}$ volumetric flask and a pure $40 \%(\mathrm{v} / \mathrm{v})$ methanol/water solution was added to a final volume of $50 \mathrm{~mL}$. Later, a $2 \mathrm{~mL}$ aliquot of this solution was diluted with pure methanol up to $25 \mathrm{~mL}$, the solution was centrifuged at $2000 \mathrm{rpm}$ for $15 \mathrm{~min}$, the supernatant was dried under vacuum at $50^{\circ} \mathrm{C}$ and the residue was dissolved in 1.2 $\mathrm{mL}$ of anhydrous pyridine.

Sample pretreatment of fresh ricotta and Ricotta mustia sheep's cheeses was done as follows: $0.5 \mathrm{~g}$ of ricotta were mixed with $0.1 \mathrm{~mL}$ of a $0.05 \%(\mathrm{w} / \mathrm{v})$ internal standard ethanolic solution and diluted to 10 $\mathrm{mL}$ with ethanol; after 1 hour at room temperature the mixture was centrifuged at $2000 \mathrm{rpm}$ for $15 \mathrm{~min}$; $8 \mathrm{~mL}$ of the supernatant were dried under vacuum at $50^{\circ} \mathrm{C}$ and the residue was dissolved in $0.8 \mathrm{~mL}$ of anhydrous pyridine.

As regards samples derivatization, 0.1 $\mathrm{mL}$ of pyridine solution obtained after the sample pretreatment step described in 2.7.1.1 or in 2.7.1.2 was kept at $0^{\circ} \mathrm{C}$ for 30 minutes, then it was sequentially treated with $0.1 \mathrm{~mL}$ of a mixture $2: 1(\mathrm{v} / \mathrm{v})$ of TMSI/TMCS, $0.1 \mathrm{~mL}$ of heptane and 0.2 $\mathrm{mL}$ of water. Finally, $1 \mu \mathrm{L}$ of this solution was injected into the GC column. Each sample was analysed in duplicate.

Gas chromatographic analysis was performed on a Hewlett-Packard 5890 Series II Gas Chromatograph (Agilent Technologies, Milan, Italy) equipped with a flame ionization detector (FID). Injector and detector temperatures were $300^{\circ} \mathrm{C}$. Chromatographic separation was carried out in a Supelco Low Bleed SLB ${ }^{\mathrm{TM}}-5 \mathrm{~ms}, 30$ $\mathrm{m} \times 0.32 \mathrm{~mm} \times 0.25 \mu \mathrm{m}$ capillary column by using nitrogen as carrier gas. Oven was held at $50^{\circ} \mathrm{C}$ for $2 \mathrm{~min}$, then it was heated first at $10^{\circ} \mathrm{C} / \mathrm{min}$ up to $130^{\circ} \mathrm{C}$ and then at $5^{\circ} \mathrm{C} / \mathrm{min}$ up to $300^{\circ} \mathrm{C}$. Temperature of the oven was held at $300^{\circ} \mathrm{C}$ for $5 \mathrm{~min}$, and then it was raised at $30^{\circ} \mathrm{C} / \mathrm{min}$ up to $360^{\circ} \mathrm{C}$. This final temperature was held for $5 \mathrm{~min}$. Data were elaborated using a HP ChemStation software (Agilent Technologies).

LOD and LOQ values for lactose have been evaluated according to literature meth- ods (Ribani et al., 2007). For ricotta samples, LOD was $1.8 \mathrm{mg} / \mathrm{kg}$, whereas LOQ was $5.6 \mathrm{mg} / \mathrm{kg}$. The LOD and LOQ values for Pecorino di Osilo were 1.35 and 4.2 $\mathrm{mg} / \mathrm{kg}$, respectively

Quantification of glucose and galactose was carried out in two samples for each batch of Pecorino di Osilo cheese, fresh ricotta cheese and Ricotta mustia cheese. Attribution of the chromatographic peaks of glucose and galactose in cheese samples were obtained both by comparing the retention times and spiking the peaks with a standard solution containing known amounts of analyte of interest. For each analyte, analytical data were expressed as sum of concentrations of all anomers.

\section{Results}

The hydrolysis of ONPG showed a $\beta$ galactosidase activity of $4950 \pm 40 \mathrm{NLU} / \mathrm{g}$, which was slightly greater than the minimal activity (4800 NLU/g) indicated by the producer. Table 1 reports mean values for proteins, fats, lactose, somatic cells and total bacterial count of the untreated raw sheep's milk used for the study (negative control) and of milk treated with different amounts of lactase. As expected, the lactose concentration decreased according to the increase of lactase concentration added to raw milk. The addition of lactase at concentration of $0.7 \mathrm{~g} / \mathrm{L}$ reduced the lactose concentration in milk of $c a$. $97 \%$ while a concentration of lactase of $1.1 \mathrm{~g} / \mathrm{L}$ was needed in order to reduce the concentration of lactose below its LOD. The addition of lactase at concentration of $1.1 \mathrm{~g} / \mathrm{L}$ was then selected for all

Table 1. Mean values ( \pm standard deviation) for proteins, fat, lactose, somatic cell count, total bacterial count of raw sheep's milk with and without addition of lactase.

\begin{tabular}{lccccc} 
Millk samples & $\begin{array}{c}\text { Proteins } \\
(\mathrm{g} / 100 \mathrm{~mL})\end{array}$ & $\begin{array}{c}\text { Fat } \\
(\mathrm{g} / 100 \mathrm{~mL})\end{array}$ & $\begin{array}{c}\text { Lactose } \\
(\mathrm{g} / 100 \mathrm{~mL})\end{array}$ & $\begin{array}{c}\text { SCC } \\
(\mathrm{Log} / 10 / \mathrm{mL})\end{array}$ & $\begin{array}{c}\text { TBC } \\
\left(\mathrm{Log}_{10} \mathrm{Cfu} / \mathrm{mL}\right)\end{array}$ \\
\hline Negative control & $5.49 \pm 0.00$ & $6.39 \pm 0.01$ & $5.01 \pm 0.02$ & $5.90 \pm 0.00$ & $4.74 \pm 0.02$ \\
$0.7 \mathrm{~g} / \mathrm{L}$ & $5.66 \pm 0.01$ & $6.43 \pm 0.01$ & $0.16 \pm 0.05$ & $5.90 \pm 0.01$ & $4.68 \pm 0.02$ \\
\hline $0.9 \mathrm{~g} / \mathrm{L}$ & $5.67 \pm 0.01$ & $6.44 \pm 0.01$ & $0.07 \pm 0.03$ & $5.90 \pm 0.02$ & $4.68 \pm 0.02$ \\
$1.1 \mathrm{~g} / \mathrm{L}$ & $5.68 \pm 0.01$ & $6.43 \pm 0.01$ & $<0.06$ & $5.89 \pm 0.01$ & $4.70 \pm 0.04$ \\
\hline
\end{tabular}

SCC, somatic cell count; TBC, total bacterial count.

Table 2. Gross composition, lactose, somatic cell count, total bacterial count and $\mathrm{pH}$ of refrigerated bulk tank raw sheep's milk samples added with $1.1 \mathrm{~g} / \mathrm{L}$ of lactase.

\begin{tabular}{ccccccc} 
Batch & $\begin{array}{c}\text { Proteins } \\
(\mathrm{g} / 100 \mathrm{~mL})\end{array}$ & $\begin{array}{c}\text { Fat } \\
(\mathrm{g} / 100 \mathrm{~mL})\end{array}$ & $\begin{array}{c}\text { Lactose } \\
(\mathrm{g} / 100 \mathrm{~mL})\end{array}$ & $\begin{array}{c}\text { SCC } \\
\left(\log _{10} / \mathrm{mL}\right)\end{array}$ & $\begin{array}{c}\text { TBC } \\
\left(\log _{10} \mathrm{cfu} / \mathrm{mL}\right)\end{array}$ & $\mathrm{pH}$ \\
\hline 1 & 5.52 & 5.70 & $<0.06$ & 5.80 & 4.81 & 6.69 \\
\hline 3 & 5.48 & 5.90 & $<0.06$ & 5.77 & 4.67 & 6.69 \\
\hline 3 & 5.55 & 6.21 & $<0.06$ & 5.89 & 5.59 & 6.67 \\
\hline
\end{tabular}

SCC, somatic cell count; TBC, total bacterial count. 
farmstead productions. Table 2 reports milk characterization, including also the $\mathrm{pH}$ value, carried out on raw sheep's milk used in each of the three experimental cheesemaking processes. No significant change in the milk proteins composition and $\mathrm{pH}$ was observed between batches while an increase in fat content was observed from batch 1 to batch 3 .

In Table 3 the results of physico-chemical and composition analysis on Pecorino di Osilo cheese, fresh ricotta and Ricotta mustia cheeses are reported. Table 4 shows the amounts of lactose, galactose, glucose and galactose/glucose ratio found in fresh Pecorino di Osilo cheese.

\section{Discussion}

The average lactose content of raw in sheep's milk (4.5-5.0 g/L) is usually slightly higher than cow's milk (4.6-4.7 g/L) (Cosseddu et al., 2008). Lactose content is generally low in colostrum and at the end of the lactation period while is constant during mid-lactation (Haenlein and Wendorff, 2006). Therefore in this period changes of lactose content are not expected to affect the standardization of the production of freelactose products.

However, the production of farmstead cheese and ricotta cheese using lactose-free raw milk should take into account structural and management practices limitation, especially of lactase use in raw milk. A structural limitation is represented by the availability of milk storage equipment that, in most of the sheep dairy farms, is represented exclusively by the refrigerated tank, with no refrigeration temperature monitoring equipment. One of the most representative issues of this research was the control of the temperature of sheep's milk before processing. The optimal temperature of milk storage is the compromise between the opposite needs of limit the growth of both psychrotrophic and pathogenic bacteria and preserving the activity of lactase. Regulatory provisions laid down by Regulation EC 853/2004 (European Commission, 2013) were also taken into account. The prolonged refrigeration of milk before transformation supports the possible growth of psychrotrophic bacterium that negatively affects cheese yield (de Garnica et al., 2011; de Moura Maciel et al., 2015). Hence, the temperature of $8^{\circ} \mathrm{C}$ for milk storing was selected mainly in order to limit the growth of psychrotrophic microflora and to preserve the activity of lactase. The lactase of $K$. lactis source shows an increase in the activity of $85-95 \%$ at $38^{\circ} \mathrm{C}$ as compared to that measured at $4-5^{\circ} \mathrm{C}$ (Mlichová and Rosenberg, 2006; Horner et al., 2011). In the cheese making process the increase of temperature during milk warming $\left(35^{\circ} \mathrm{C}\right)$ and the cooking of curd $\left(42^{\circ} \mathrm{C}\right)$, allow the complete hydrolysis of the residual lactose before the curd acidification drops $\mathrm{pH}$ below 5.5, limiting the activity of the lactase. Laboratory experimentation demonstrated that in sheep's milk lactase concentration of 1.1 $\mathrm{g} / \mathrm{L}$ is needed to reduce lactose concentration below the LOD of the enzymatic method $(0.06 \mathrm{~g} / 100 \mathrm{~mL})$. The high concen- tration of lactase needed was probably due to the specific operative conditions rather than the use of raw sheep's milk. In cow's milk, no differences have been observed in lactase activity in relation to the type of milk (raw or pasteurized) or in relation to milk fat content (Horner et al., 2011). The only modification proposed in the manufacturing of lactose-free variants of Pecorino di Osilo, fresh ricotta and Ricotta mustia cheeses, was the replacement of raw sheep's milk with the lactose-free sheep's milk. The aim was to preserve as much as possible organoleptic and quality features of these artisanal cheeses. For evaluating traces of lactose in these cheeses, a sensitive GC-FID method specifically devoted to accurately measure lactose and its hydrolysis products (i.e. galactose and glucose) has been developed and used. The lactose LOD value in Pecorino di Osilo cheese was $1.35 \mathrm{mg} / \mathrm{kg}$, whereas in ricotta cheeses it was $1.8 \mathrm{mg} / \mathrm{kg}$ (i.e. more than two orders of magnitude less than LOD with the enzymatic method). Lactose was measured after 24 hours and 30 days from its production in Pecorino $d i$ Osilo cheese, after 2 days from the date of production in fresh ricotta and after 7 days from production in Ricotta mustia. All samples in this study showed always a lactose concentration below the relevant LOD. In addition, the GC-FID method has allowed us to evaluate the amounts of galactose and glucose in all samples within the first seven days after production. The concentrations of monosaccharides found in the three dairy products considered in this study are rather different among them. Galactose and glu-

Table 3. Physico-chemical composition of Pecorino di Osilo cheese (30 days of ripening), fresh ricotta cheese (48 hours after production) and Ricotta mustia cheese (7 days after production).

\begin{tabular}{|c|c|c|c|c|c|c|c|c|c|}
\hline \multirow[b]{2}{*}{ Parameter/batch } & \multirow[b]{2}{*}{1} & \multicolumn{2}{|c|}{ Pecorino di Osil } & \multicolumn{3}{|c|}{ Fresh ricotta } & \multicolumn{3}{|c|}{ Ricotta mustia } \\
\hline & & 2 & 3 & 1 & 2 & 3 & 1 & 2 & 3 \\
\hline $\mathrm{pH}$ & $5.30 \pm 0.03$ & $5.14 \pm 0.01$ & $5.13 \pm 0.01$ & $6.54 \pm 0.02$ & $6.50 \pm 0.02$ & $6.65 \pm 0.03$ & $5.4 \pm 0.3$ & $5.8 \pm 0.2$ & $6.0 \pm 0.3$ \\
\hline$a_{w}$ & $0.97 \pm 0.00$ & $0.97 \pm 0.00$ & $0.96 \pm 0.00$ & $0.990 \pm 0.005$ & $0.988 \pm 0.006$ & $0.988 \pm 0.006$ & $0.970 \pm 0.004$ & $0.972 \pm 0.003$ & $0.976 \pm 0.002$ \\
\hline Moisture (g/100 g) & $37.05 \pm 0.20$ & $37.6 \pm 0.3$ & $37.1 \pm 0.5$ & $75 \pm 1.0$ & $76 \pm 2.0$ & $73 \pm 2.0$ & $65 \pm 1.0$ & $62 \pm 1.0$ & $64 \pm 1.0$ \\
\hline Fat $(\mathrm{g} / 100 \mathrm{~g})$ & $30.35 \pm 0.15$ & $30.5 \pm 0.2$ & $31.4 \pm 0.5$ & $12.7 \pm 0.4$ & $12 \pm 2.0$ & $12 \pm 1.0$ & $15 \pm 1.0$ & $19 \pm 0.1$ & $18.3 \pm 0.7$ \\
\hline Proteins (g/100 g) & $30.0 \pm 0.2$ & $29.05 \pm 0.15$ & $29.0 \pm 0.3$ & $9.2 \pm 0.4$ & $8.8 \pm 0.1$ & $9.5 \pm 0.4$ & $13.4 \pm 0.4$ & $12.9 \pm 0.3$ & $12.7 \pm 0.4$ \\
\hline Lactose (mg/kg) & $<1.35^{\circ}$ & $<1.35^{\circ}$ & $<1.35^{\circ}$ & $<1.8^{\circ}$ & $<1.8^{\circ}$ & $<1.8^{\circ}$ & $<1.8^{\circ}$ & $<1.8^{\circ}$ & $<1.8^{\circ}$ \\
\hline $\mathrm{NaCl}(\mathrm{g} / 100 \mathrm{~g})$ & $1.31 \pm 0.01$ & $1.35 \pm 0.04$ & $1.41 \pm 0.03$ & - & - & - & $1.31 \pm 0.01$ & $1.35 \pm 0.04$ & $1.41 \pm 0.03$ \\
\hline
\end{tabular}

$\mathrm{a}_{w}$, water activity. ${ }^{\circ}<$ limit of detection.

Table 4. Average amounts of lactose, galactose, glucose and galactose/glucose ratio in sheep's milk cheese produced by delactosed milk.

\begin{tabular}{|c|c|c|c|c|c|c|}
\hline & $\begin{array}{l}\text { Samples } \\
\text { (n) }\end{array}$ & $\begin{array}{l}\text { Ripening time } \\
\text { (days) }\end{array}$ & $\begin{array}{l}\text { Lactose } \\
(\mathrm{mg} / \mathrm{kg})^{\circ}\end{array}$ & $\begin{array}{c}\text { Galactose } \\
(\mathrm{mg} / \mathrm{kg} \pm \mathrm{SD})\end{array}$ & $\begin{array}{c}\text { Glucose }^{\#} \\
(\mathrm{mg} / \mathrm{kg} \pm \mathrm{SD})\end{array}$ & Galactose/glucose ratio \\
\hline Fresh ricotta & 6 & 2 & $<1.8$ & $1100 \pm 300$ & $1200 \pm 300$ & 0.92 \\
\hline Ricotta mustia & 6 & 7 & $<1.8$ & $950 \pm 400$ & $750 \pm 250$ & 1.27 \\
\hline Pecorino di Osilo & 6 & 0 & $<1.35$ & $13,000 \pm 2000$ & $11,000 \pm 2000$ & 1.18 \\
\hline
\end{tabular}

SD, standard deviation. ㄴimit of detection value for the considered matrix; "expressed as sum of anomers. Analyses were performed by means of the gas chromatography-flame ionisation detection method. 
cose are ten times more abundant in fresh Pecorino di Osilo cheese than in ricotta cheeses. The amounts of monosaccharides found in fresh cheese are coherent with the amount contained in the whey retained in this cheese. In addition, the very short ripening time elapsed from production has probably prevented the further degradation of these compounds. Overall the concentration of galactose and glucose showed a great variability in sheep's fresh cheeses. The average concentration of galactose and glucose in fresh Pecorino di Osilo was $13,000 \pm 2000$ and $11,000 \pm 2000 \mathrm{mg} / \mathrm{kg}$, respectively. In fresh ricotta, the concentration of galactose and glucose was respectively $1100 \pm 300$ and $1200 \pm 300 \mathrm{mg} / \mathrm{kg}$, whereas in Ricotta mustia were $950 \pm 400$ and $750 \pm 250 \mathrm{mg} / \mathrm{kg}$. The overall quantity of monosaccharides observed in fresh ricotta is ca. 35\% higher than in Ricotta mustia. Glucose is the monosaccharide that prevails in the fresh ricotta, while galactose is more abundant than glucose in Ricotta mustia $(\mathrm{P}>0.05)$. The amount of galactose and glucose found in both ricotta cheeses are much lower than those expected on the basis of the high amount in the whey remaining after ricotta cheese production. It is evident that in milk whey and then in both fresh ricotta and Ricotta mustia cheese some degradation phenomena occurred and they are active in reducing the concentrations of these monosaccharides. Finally, our results demonstrated that the residual lactose in the Pecorino di Osilo cheese, in the fresh ricotta and in the Ricotta mustia are always below the relevant detection limits calculated for the GC-FID method. Due to the very low LOD values, lactose quantification with the chromatographic method is the best guarantee for claiming lactose-free in dairy products. This is of particular relevance for Pecorino di Osilo cheese, fresh ricotta cheese and the Ricotta mustia cheese which lactose content should be less than 1/500 the limit of $100 \mathrm{mg} / 100 \mathrm{~g}$ determined by the Italian law (Italian Ministry of Health, 2015). The present study allowed validating the production process of Pecorino di Osilo cheese, fresh ricotta and Ricotta mustia cheeses obtained from lactose-free sheep's milk and whey. In fact, the three production replicates needed only little adjustment of the ordinary operating procedures (i.e. addition of lactase after morning milking) having no impact on the processing daily routine. The residual lactose was always below the detection limit, demonstrating the feasibility of producing lactose-free products at farmstead level without changing the tradi-

\section{Conclusions}

In the present work the conditions of use of lactase for the artisanal production of raw milk sheep cheese and ricotta were defined. The technology of production of traditional Pecorino di Osilo, fresh ricotta and Ricotta mustia cheeses was applied to an experimental trial conducted in a farmstead cheese making facility in order to obtain lactose-free products. The results obtained showed the feasibility of obtaining lactose-free product at artisanal level. The major issues for farmstead cheese-makers are to develop adequate procedures, in the frame of their HACCP plan, to guarantee the effectiveness of the process and to acquire analytical data to demonstrate in the final product the compliance of the residual lactose concentrations with the legislation requirements for the lactose-free labelling.

\section{References}

AOAC, 1999. AOAC official method 998.04. Association of Official Analytical Chemists, Washington, DC, USA.

Baroke S, 2016. Does lactose-free dairy have a future? Available from: http://blog.euromonitor.com/2016/04/d oes-lactose-free-dairy-have-afuture.html

Beyerlein L, Pohl D, Delco F, Stutz, Fried M, Tutuian R, 2008. Correlation between symptoms developed after the oral ingestion of $50 \mathrm{~g}$ lactose and results of hydrogen breath testing for lactose intolerance. Aliment Pharmacol Ther 27:659-65.

Casellas F, Aparici A, Casaus M, Rodríguez P, Malagelada JR, 2010. Subjective perception of lactose intolerance does not always indicate lactose malabsorption. Clin Gastroenterol Hepatol 8:581-6.

Chen W, Chen H, Xia Y, Yang J, Zhao J, Tian F, Zhang HP, Zhang H, 2009. Immobilization of recombinant thermostable beta-galactosidase from Bacillus stearothermophilus for lactose hydrolysis in milk. J Dairy Sci 92:4918.

Cosseddu AM, De Santis EPL, Serraino A, 2008. Igiene e tecnologie del latte del colostro e dei prodotti derivati. In: AM Cosseddu, E De Santis, A Serraino (eds.) Igiene e tecnologie degli alimenti di origine animale. Le Point Veterinaire Italia, Milan, Italy, pp 203-57.

de Garnica ML, Santos JA, Gonzalo C, 2011. Influence of storage and preservation on microbiological quality of silo ovine milk. J Dairy Sci 94:1922-7.

de Moura Maciel G, Hammershøj M, Frederiksen PD, Sørensen J, Bakman M, Poulsen NA, Larsen LB, 2015.
Dairy processing and cold storage affect the milk coagulation properties in relation to cheese production. Dairy Sci Technol 95:101-14.

EFSA, 2010. Scientific opinion on lactose thresholds in lactose intolerance and galactosaemia. Available from: https://www.efsa.europa.eu/it/efsajour$\mathrm{nal} / \mathrm{pub} / 1777$

European Commission, 2011. Regulation of the European Parliament and of the Council of 25 October 2011 on the provision of food information to consumers, 1169/2011/CE. In: Official Journal, L 304, 22/11/2011.

European Commission, 2013. Regulation of the European Parliament and of the Council of 12 June 2013 on food intended for infants and young children, food for special medical purposes, and total diet replacement for weight control, 609/2013/CE. In: Official Journal, L 181, 29/06/2013.

Haenlein GFW, Wendorff WL, 2006. Sheep milk in handbook of milk of non-bovine mammals. Blackwell Publishing, Ames, IA, USA.

Horner TW, Dunn ML, Eggett DL, Ogden LV, 2011. $\beta$-galactosidase activity of commercial lactase samples in raw and pasteurized milk at refrigerated temperatures. J Dairy Sci 94:3242-9.

Idda I, Spano N, Ciul, M, Nurchi VM, Panzanelli A, Pilo MI, Sanna G, 2016. Gas chromatography analysis of major free mono- and disaccharides in milk: Method assessment, validation, and application to real samples. J Sep Sci 39:4577-84.

ISO, 2006. Milk. Enumeration of somatic cells. Part 2: guidance on the operation of fluoro-opto-electronic counters. ISO Norm 13366:2006/IDF 148-2:2006. International Organization for Standardization, Geneva, Switzerland.

ISO, 2010. Milk. Determination of lactose content. Enzymatic method using difference in $\mathrm{pH}$. ISO Norm 26462:2010/IDF 214:2010. International Organization for Standardization, Geneva, Switzerland.

ISO, 2013. Milk and liquid milk products. Guidelines for the application of midinfrared spectrometry. ISO Norm 9622:2013/IDF 141:2013. International Organization for Standardization, Geneva, Switzerland.

ISTAT, 2015. Consultazione dati, agricoltura e zootecnica. Available from: http://agri.istat.it/sag_is_pdwout/jsp/ $\mathrm{Ne}$ wExcel.jsp?id=8A|11 A\&anid $=2015$

Italian Ministry of Health, 2015. Directorate-general for hygiene, food safety and nutrition. Ministerial note, 
Prot. N. 00027673-P 07.07.2015. Updates following regulatory developments due to the entry to force of the Regulation (EU) 609/2013. Available from: http://www.trovanorme .salute.gov.it/norme/renderNormsanPdf ?anno $=0 \&$ codLeg $=52396 \&$ parte $=1 \% 2$ $0 \&$ serie $=$

Italian Ministry of Health, 2016a. Directorate-General for hygiene, food safety and nutrition. Ministerial note, Prot. N. 00024708-P 16.06.2016. Updates on food supplements, analytical tolerance that should be applied on official control and indications on lactosefree or lactose-reduced milk and dairy products. Available from: http://www.trovanorme.salute.gov.it/nor $\mathrm{me} /$ renderNormsanPdf?anno $=2016 \& \mathrm{co}$ $\mathrm{dLeg}=55383 \&$ parte $=1 \% 20 \&$ serie $=$ null

Italian Ministry of Health, 2016b. Directorate-General for hygiene, food safety and nutrition. Ministerial note, Prot. N. 00031769-P 04.08.2016. Approval of production and packaging establishments of products that fall in Regulation 609/2013 enforcement field, repealing the sector of Foodstuffs for particular nutritional uses. Available from: http://www.trovanorme.
salute.gov.it/norme/renderNormsanPdf ?anno $=2016 \&$ codLeg $=55675 \&$ parte $=1$ $\% 20 \&$ serie $=$ null

Jelen P, Tossavainen O, 2003. Low lactose and lactose-free milk and dairy products: prospects, technologies and applications. Aust J Dairy Technol 58:161-5.

Kies AK, 2014. Authorised EU health claims related to the management of lactose intolerance: reduced lactose content, dietary lactase supplements and live yoghurt cultures. In: Foods, nutrients and food ingredients with authorised EU health claims. Woodhead Publ., London, UK, pp 177-211.

Lule VK, Garg S, Tomar SK, Khedkar CD, Nalage DN, 2016. Food intolerance: lactose intolerance. In: Caballero B, Finglas PM, Toldrá F (eds.) Encyclopedia of food and health. Academic Press, Oxford, UK, pp. 43-8. MIPAAF, 2016. Decree of the 23 may 2016 of the Italian Ministry of Agricultural, Food and Forestry Policies. In: Official Journal, General Series n. 143, 21.06.2016. Available from: http:/www.gazzettaufficiale.it/eli/id/20 16/06/21/16A04569/sg;jsessionid=JP0 Qfr2kNjYsXQJRy3JQ6w_.ntc-as5guri2b
Mlichová Z, Rosenberg M, 2006. Current trends of $\beta$-galactosidase application in food technology. J Food Nutr Res 45:47-54.

Oliveira C, Guimarães PMR, Domingues L, 2011. Recombinant microbial systems for improved $\beta$-galactosidase production and biotechnological applications. Biotechnol Adv 29:600-9.

Ribani M, Collins CH, Bottoli CBG, 2007. Validation of chromatographic methods: evaluation of detection and quantification limits in the determination of impurities in omeprazole. J Chromatogr A 1156:201-5.

Troyano E, Olano A, Fernández-Díaz M, Sanz J, Martínez-Castro I, 1991. Gas chromatographic analysis of free monosaccharides in milk. Chromatographia 32:379-82.

Troyano E, Olano A, Martínez-Castro I, 1994. Changes in free monosaccharides during storage of dried milk. J Agr Food Chem 42:1543-5.

Troyano E, Villamiel M, Olano A, Sanz J, Martínez-Castro I, 1996. Monosaccharides and myo-inositol in commercial milks. J Agr Food Chem 44:815-7. 